\title{
Gandhi: A Man for our Times?
}

\author{
Judith Brown \\ judith.brown@history.ox.ac.uk
}

\section{Abstract}

Following my earlier collaboration with Martin Prozesky, my essay links with three major concerns in Prozesky's work as he has engaged with a radical critique of religious traditions and structures in the South African context of the end of apartheid: the involvement of dominant religious traditions in sustaining power structures and inequality; the nexus between religious beliefs and organizations and violence; and the failure of many 'religions' to meet the needs of serious seekers after meaning and truth. In this context, I examine the life and thought of M.K. Gandhi, particularly the way he addressed the nature of India and its problems as British imperial rule ended. It also focuses on Gandhi's critique of Hindu tradition as a powerful buttress of profound social inequality particularly relating to caste and gender; his response to violence in the name of religion and community; and finally his underlying belief that true religion was the individual's search for the divine and that all religious traditions by contrast have very partial visions of truth. Finally, in my view, Gandhi should be seen not just as an important historical figure but very much as a man for our times also.

Keywords: Religious tradition, religious structures, apartheid, inequality, violence, truth, M.K. Gandhi, Hindu tradition, caste, gender

It is a privilege to be invited to contribute an essay in this volume honouring the work of Professor Martin Prozesky, who has been to me a friend and colleague, although I work on another continent, and in a different academic 
discipline. One of the pleasures as well as the strengths of contemporary academia is its global nature: scholars are no longer locked in their own national worlds, and their concerns and experiences can be shared across the world in truly global interactions.

Martin's work lies broadly in the field of religious studies; but not in the narrow sense of examining the internal beliefs and dynamics of religious traditions and the communities they give rise to. He has worked at the 'edges' of the discipline, where it interacts with politics and history, for example. Studying, teaching and communicating to a broader thoughtful public, in the particular context of South Africa and its turbulent but creative recent history, he has examined and critiqued at least three aspects of established religious traditions and structures as they interact with the society around them. These three themes reappear in his work - the involvement of dominant religious traditions in sustaining power structures and inequality, the nexus between religious beliefs and organizations and violence, and the failure of many 'religions' to meet the needs of serious seekers after meaning and truth.

These concerns bring to mind M.K. Gandhi, who came to maturity as a thinker, and as a political activist during his two decades working in South Africa, before he became notable in India as a 'great soul' or Mahatma, and as someone who had the courage to challenge political, social and religious authorities in India under British imperial rule. Gandhi came to wrestle with the three great issues which have undergirded much of Martin's work. His years championing the Indian community in South Africa from 1894, when he first came to the country on a temporary contract as a lawyer, were years of seeking and experimentation, of self-examination and reflection. They came to fruition back in India from 1914 until his assassination in 1948 - in his voluminous speeches and writings, in the simple religious communities, ashrams, he founded and made his home, in his increasingly spartan lifestyle, and of course in his refinement of peaceful resistance to wrongs both social and political, in the form of satyagraha ${ }^{1}$. It is appropriate to examine Gandhi's

${ }^{1}$ The major published source for Gandhi's life, his speeches and writings is the 100 volume Collected Works of Mahatma Gandhi (1958-). A convenient collection of Gandhi's writings on key issues is J. Brown (ed.), Mahatma Gandhi: The Essential Writings (New Edition, 2008). On Gandhi's time in South Africa there is also his autobiography which covers his life to the 1920s, and his account of his practice of non-violence, An Autobiography: The Story 


\section{Judith Brown}

thinking and work in relation to these three issues, not just because of their relation to Martin's own work, but because, in a happy coincidence, I first met Martin at a conference in Pietermaritzburg in 1993 to honour the work of Gandhi in South Africa ${ }^{2}$.

The background to Gandhi's work in India were the final decades of British imperial rule. Political power was at stake in a diverse and plural society, first through a series of constitutional reforms, and second with the prospect of independence. People were increasingly forced to ask themselves in both hope and fear crucial questions about the nature of Indian identity, and what a new Indian nation state would look like. Would the new India, emerging from the end of British rule, be plural and inclusive of the Hindu majority and significant minorities such as Muslims, and Sikhs, or would it be built on an uncompromisingly Hindu vision of Indian-ness? Would the new state represent and care for the weak and less valued members of society, particularly those considered to be 'untouchable' in Hindu ritual hierarchy, or of course the vast majority of Indian women who had far lower status than men and virtually no political voice. Gandhi's work encompassed far more than 'politics' as commonly understood. Certainly he involved himself in the campaign for national freedom from imperial rule, and was a crucial figure in the politics of the Indian National Congress, which was the main nationalist organization and voice. But far more important to him was grass roots work to make Indians self-reliant, and to generate an inclusive sense of nationhood beyond religious and regional differences, and beyond social divisions and gross inequalities of wealth and status. This was what he called swaraj or true self-rule. His original manifesto proclaiming his vision of what a new India might look like was Hind Swaraj, a pamphlet written in $1909^{3}$. He never retracted it. He went on to argue that the work of social reconstruction was far more important for India's future than political campaigning or even movements of non-violent resistance to

of My Experiments with Truth (1927); and Satyagraha in South Africa (1928). While in South Africa Gandhi also wrote his key book on the meaning of selfrule (swaraj) for India, Hind Swaraj (1909). It is available in CWMG, X: 6-68. The best modern edition is Parel's Gandhi: Hind Swaraj and Other Writings (1997).

${ }^{2}$ This conference gave rise to the volume co-edited by us, Gandhi and South Africa: Principles and Politics (1996).

${ }^{3}$ See reference to Parel's edition in note 1. 
British rule ${ }^{4}$.

Given the religious complexity of Indian society and the way religious traditions were interwoven with social practice and political organization, Gandhi could not have avoided serious engagement with the nature of religion on the subcontinent. Nor would he have wanted to. A Hindu by birth, he was on his own admission unimpressed by its practice and teaching as a young man, and knew little of its scriptures. It was the experiences of his student days in England and then his life in South Africa which drew him to reconsider his own religious inheritance and also to investigate the insights of other traditions. As he wrote in his autobiography, 'I had gone to South Africa for travel ... and for gaining my own livelihood. But ... I found myself in search of God and striving for self-realization' ${ }^{5}$. Although Gandhi remained a Hindu all his life, and counselled that all people should remain within their own traditions rather converting to another one, his own understanding of religion was deeper and broader than a commitment to a particular tradition or a particular way of seeing or searching for the divine. He came to believe that Truth was God, and that the authentic human life was to engage in a search for that Truth. Truth undergirded and lay deep within all living things, and so service of all life, and particularly of the poorest and least regarded of humanity, was the surest way to understanding something of Truth. As he wrote in a letter in $1932^{6}$,

The purpose of life is undoubtedly to know oneself. We cannot do it unless we learn to identify ourselves with all that lives. The sum total of that life is God. Hence the necessity of realizing God living within

${ }^{4}$ See the sources gathered in section IV of J. Brown (ed.), Gandhi: The Essential Writings. Particularly significant was a pamphlet he wrote in December 1941, 'Constructive Programme: Its Meaning and Place' (in Brown 2008:164-184).

${ }^{5}$ Gandhi, An Autobiography, II, Chapter XXII. The autobiography provides a good introduction to Gandhi's religious thinking. As he wrote in the introduction his purpose was not to write an autobiography as commonly understood but to tell the story of his 'experiments with truth' - hence the subtitle of the work. See also the documents chosen in section II of Brown's Gandhi: The Essential Writings.

${ }^{6}$ J. Brown (ed.): Gandhi: The Essential Writings (2008:41). 


\section{Judith Brown}

every one of us. The instrument of this knowledge is boundless selfless service.

This belief in service as the route to knowledge of the divine drew him into many aspects of work for the poor and despised, the underprivileged, the sick and the very poor. Perhaps the most notable among his many ostensibly 'social' campaigns were those for the abolition of the status of Untouchability, and for the reform of many customs relating to women which prevented them from reaching their potential as human beings and contributing to the life of their country. But his understanding of the meaning of true religion also drew him into what his contemporaries understood as politics. As he concluded his autobiography he stated this clearly.

To see the universal and all-pervading Spirit of Truth face to face one must be able to love the meanest of creation as oneself. And a man who aspires after that cannot afford to keep out of any field of life. That is why my devotion to Truth has drawn me into the field of politics; and I can say without the slightest hesitation, and yet in all humility, that those who say that religion has nothing to do with politics do not know what religion means ${ }^{7}$.

Obviously, Gandhi's priorities and practices marked him out as very different from most of those who were politically active in India at the time of his return to his homeland in 1915. Many thought him a very strange person indeed, commenting on his refusal to wear European dress as many Indian professional men among his contemporaries did, his extraordinarily restricted vegetarian diet, as well as more widely on his ideas and his ashram homes. Although he soon became known by the title of Mahatma after his return to India, he began to engage in a highly critical manner with the practice of religion and its impact on private and public life. Some of his fiercest criticism and most radical critiques focussed on the first of the great themes outlined at the start of this essay - the involvement of dominant religious traditions in sustaining power structures and inequality. Gandhi had comparatively little to say about the link between Christianity and British imperialism. (His major critique of British imperialism, as shown in Hind Swaraj, rested on his belief

${ }^{7}$ Cf. Gandhi's 'Farewell', in An Autobiography. 
that it was the herald of a so-called civilization bereft of God, which was corrupting Indians and their society.) Given that Gandhi's goal was to transform Indian society from within, and to create a new form of polity, he concentrated on the traditions of the majority of Indians - namely the cluster of traditions and practices which were increasingly known as 'Hinduism' ${ }^{8}$. His own understanding of true religion was far broader than that of many Hindus at the time, and his personal practice far more eclectic ${ }^{9}$. He therefore had no hesitation in pointing out the ways in which cultural practices of dominance and discrimination were rooted in Hindu thinking and practice, and arguing that these must be rooted out if India was to flourish as a truly self-regulating polity. In his view such practices were morally wrong and also deeply dysfunctional in the context of creating swaraj.

As already noted, he spent considerable time and energy on issues of caste and gender. On questions relating to caste he was always in adult life totally opposed to treating some people as ritually polluting and therefore untouchable. He called untouchability 'the greatest blot on Hinduism' ${ }^{10}$. This had been clear even in South Africa, when he welcomed into his home those whom high caste Hindus would have considered polluting. (This caused considerable tension between Gandhi and his wife.) It nearly wrecked his first ashram home in India when he admitted an 'Untouchable' family and caste Hindus withdrew their charitable funding. It became one of the cornerstones of

8 'Hinduism' is a very recent word and concept. Until the $19^{\text {th }}$ century a 'Hindu' was the name given to someone from India. It was a term of geographical origin as in the description of British people holidaying from India in the Cape who were known as 'Hindus'. It became a term of religious identification in the later $19^{\text {th }}$ century as many Indian religious reforms sought to present their traditions to a wider world as 'a religion' as understood in western thought and language.

${ }^{9}$ In his personal practice and in his ashram communities, Gandhi had no hesitation in using the forms of worship and prayer practised by Christians, for example. He would often use Christian hymns, among his favourites being John Henry Newman's 'Lead Kindly Light'. Sometimes visiting English people would, much to their embarrassment, be asked to lead the singing of such hymns.

${ }^{10}$ Speech in Ahmedabad, 1921, in J. Brown (ed.): Gandhi: The Essential Writings (2008: 210-212). 


\section{Judith Brown}

his constructive work for a new India. As the years passed in India itself he became increasingly radical on the far wider issue of caste as a system of social and often economic hierarchy, buttressed by practices of social separation which allocated ritual status to individuals at birth, and prevented people from different ritual groups from eating together or intermarrying. Similarly he began to campaign on gender practices and attitudes which drew on Hindu tradition to sustain the dominance of men in society and to reduce women to a permanent state of inequality both in the household and in the public sphere. His criticisms ranged from the wearing of heavy jewellery by women, their seclusion in the home in many parts of society ${ }^{11}$, their lack of education, and the traditions of child marriage and hostility to widow remarriage, even when the widow was still very young. He also rounded on prevailing ideas of 'masculinity', which did not value women as highly as men, and often led to profound public discourtesy to or harassment of women, so buttressing the notion that women of good moral and social standing should not be seen about in public space, participating in public life or in the political campaigns of the nascent nation. He challenged contemporary understanding of manliness in his own life style and in his insistence that true courage lay not in aggressive or violent behaviour, but in the ability to suffer for the sake of right. Moral probity and spiritual strength were in his eyes the desirable marks of a new Indian manliness.

Beneath Gandhi's critique of particular attitudes and customs, through which Hinduism buttressed social and economic inequalities, lay a far deeper concern - namely the reform of Hindu 'tradition' itself. In challenging tradition he was addressing the very bedrock of religious belief and observance. To do this he drew on his own understanding of what true religion meant. Given that for him true religion was the individual's search for Truth, he placed a lower value on scripture and tradition as authority in religious matters than did most orthodox Hindu contemporaries. The Hindu scriptures were important to him, and he had a particular devotion to the Bhagavad Gita. Tradition also had its place but needed to be weighed and sometimes challenged, primarily by the exercise of conscience and reason. Indeed conscience was probably his own greatest authority in religious and moral issues. He experienced this as a voice deep within himself. In 1932 he wrote in a private letter,

${ }^{11}$ Purdah, or the veiling of women and their seclusion in the home, was not just a Muslim practice. It was often a mark of high caste status, too. 
For me the reasoned course of action is held in check subject to the sanction of the inner voice. I do not know if others would call it the mysterious power .... I have never deliberated upon this nor analysed it, I have felt no need of doing so either. I have faith, and knowledge, too, that a Power exists beyond reason. This suffices for $\mathrm{me}^{12}$.

Writing publicly in one of his papers the next year about a fast he was intending to undertake he described how a terrible inner struggle was resolved by hearing this inner voice.

It was as unmistakable as some human voice definitely speaking to me, and irresistible .... Suddenly the Voice came upon me. I listened, made certain it was the Voice and the struggle ceased ${ }^{13}$.

He was experienced and wise enough to recognise that there is great scope for self-deception in religious matters, and particularly in a sense of divine guidance. Much preparatory work of self-discipline was needed to fit anyone to listen to the divine voice within. As he said in 1939, 'This listening ... presupposes fitness to listen, and the fitness is acquired after constant and patient striving and waiting on God, ${ }^{14}$.

However, Gandhi did not only engage with the way Hindu traditions sustained inequality and threatened to undermine the project of true swaraj. He was also deeply distressed by the way in which religious affiliation even more broadly was increasingly giving rise to violence in Indian public life, tearing apart the fabric of society and ultimately rending the subcontinent into two in 1947 when the British left. The sources of this conflict in the name of religion, often known as 'communalism', are among the most studied and least understood of the many issues contributing to the processes of independence and partition. This essay is not the place to rehearse contemporary scholarship. It is enough to say that even before Gandhi returned finally to India in 1915 he was disturbed at the growing rhetoric which identified Indian identity as being

1225 May 1932, in J. Brown (ed.): Gandhi: The Essential Writings (2008:48). ${ }_{13}$ Harijan, 8 July 1933, in J. Brown (ed.): Gandhi: The Essential Writings (2008:48f).

${ }^{14}$ Harijan, 7 October 1939, in J. Brown (ed.): Gandhi: The Essential Writings (2008:50). 


\section{Judith Brown}

Hindu (as opposed to Muslim or Christian for example). He devoted much attention to this in Hind Swaraj. Once back in India he made communal unity one of the cornerstones of his definition of true swaraj, and threw himself, often at great personal cost, into work to unite Hindus and Muslim in the common cause of a united, independent India.

Gandhi addressed the issue of escalating division and violence in the name of religion at different levels of his public and private life. As we have noted, he believed that the essence of true religion was the individual's search for truth, manifested in service of others. He argued that no one religious tradition had a monopoly of truth, but that all had some glimpses of truth. Using the metaphor of truth as a diamond, loved by the Jains in his native Gujarat, he said that each individual and tradition has some sense of different facets of truth but that no one and no 'religion' can grasp the radiant totality of truth. So every person and every religious community should honour others and their grasp of truth and their ongoing search for it. Late in life, looking back on his long association with non-Hindus from his childhood and his days as a student in London, he wrote in a private letter,

I have realised that every religion contains both truth and untruth. The root of all religions is one and it is pure and all of them have sprung from the same source ${ }^{15}$.

He put this belief into practice as well as into words, maintaining close friendships with Hindus and Christians, among others, and drawing on their traditions in his ashram worship.

Building on this understanding he deployed a rhetoric of fraternity among religious groups as part of the creation of a new India. All those who wished to belong to India were welcome within it, all had contributions to make to its new identity, and India had for many centuries been home to numerous faith traditions and communities. In particular he argued that there could be no identification of Indian identity with Hindu identity. Muslims and Hindus, as the two major religious communities in India, needed to realise that they were like brothers, or like two eyes in one face. Without this unity which lay deeper than religious affiliation there could be no real swaraj. He had argued this even

151 November 1945, in J. Brown (ed.): Gandhi: The Essential Writings (2008:50f). 
before he returned to India finally, when writing his pamphlet, Hind Swaraj, in $1909^{16}$. When confronted with the reality of communal mistrust and violence in India itself he threw himself into combatting it. In 1924 he wrote a lengthy article on the subject in his paper, Young India, entitled 'Hindu-Muslim Tension: Its Cause and its Cure', which was later reprinted as a pamphlet ${ }^{17}$. In its conclusion he wrote,

The reader of Young India will pardon me for devoting practically the whole of Young India to the question of Hindu-Muslim unity. He will readily do so if he holds with me that there is no question more important and more pressing than this. In my opinion, it blocks all progress.

Despite all his efforts in public persuasion and his support for Muslim concerns, Gandhi was by the mid-1920s acknowledging that none of his work seemed to be making any difference. He had thought he was an expert in solving the problem, but discovered to his sorrow that he was not, and could not offer any solution to his countrymen ${ }^{18}$. In retrospect the historian can see that communal tension and violence was far more complex than Gandhi understood it to be; and that the drivers of this corrosive disunity among Indians had comparatively little to do with religious belief, and were compounded by demography, economic status and aspiration. In particular division and hostility were reinforced by the circumstances of imperial rule and its likely ending, as the British devolved political power to Indians through mechanisms which recognised religious groups as one of many different status groups needing special representation and protection.

By the end of 1927 Gandhi was writing publicly that the only contribution he could make to the problem of communal disunity was 'prayer and such individual acts of friendship as are possible' ${ }^{19}$. However, he had one

${ }^{16}$ Hind Swaraj, Chapter X.

${ }^{17}$ For considerable quotation from this, see J. Brown (ed.): Gandhi: The Essential Writings (2008:195-204).

${ }^{18}$ Speech in Madras, The Hindu, 9 March 1925, in J. Brown (ed.): Gandhi: The Essential Writings (2008:207).

${ }^{19}$ Young India, 1 December 1927, in J. Brown (ed.), Gandhi: The Essential Writings (2008: 50f). 


\section{Judith Brown}

more 'weapon' in his armoury which he deployed in the dark days of 19461947 when it became clear that not only was a free India to be partitioned in the name of religion, but that the preparation for independence would be scarred by wide-scale and atrocious violence ${ }^{20}$. Gandhi came to an understanding of the possibility of peaceful resistance to wrongs of many kinds while he was in South Africa. It came to be far more than a tactic for him, and was embedded in his understanding of the nature of Truth. If no individual or group had a monopoly of understanding Truth, then each must respect the beliefs and wishes of the other. In any situation of conflict the truth-seeker must in conscience follow his or her sense of truth, but must also respect that of the opponent, and must therefore seek for peaceful change and a growth in understanding among all parties. Violence was a denial of the nature and power of Truth. This in practice gave rise to what he named as satyagraha, or truth force. Throughout his life he was continually experimenting with different forms of satyagraha, of putting into practice this way of achieving lasting change. He believed that peaceful resistance to wrong was very different from what was commonly known as 'passive resistance', and that it required great courage and careful planning and thought. He remained convinced of its potential and efficacy right to the end of his life, despite its apparent 'failure' in India ${ }^{21}$. In the context of escalating communal violence Gandhi personally threw himself into areas of conflict at great personal danger to himself in an attempt to protect minority communities and to bring majority groups to some sense of what they were doing. Perhaps the greatest examples of his personal practice of satyagraha were his presence in a Bengali village in the wake of anti-Hindu violence, a subsequent walking tour on foot in riot-torn villages, and then further work of reconciliation in neighbouring Bihar where Muslims

20 There is a considerable literature on the violence which accompanied independence and partition. Broad accounts are in Ian Talbot and Gurharpal Singh, The Partition of India (2009); and Yasmin Khan, The Great Partition: The Making of India and Pakistan (2007).

${ }^{21}$ On the far wider issue of the circumstances in which peaceful resistance could achieve tangible results, see Adam Roberts and Timothy Garton Ash, Civil Resistance and Power Politics: The Experience of Non-violent Action from Gandhi to the Present (2009). In particular see Brown, 'Gandhi and Civil Resistance in India, 1917-1947: Key Issues', in Roberts and Garton (2009:44 - 57). 
had been the victims and Hindus the aggressors. At partition he returned to Calcutta, the capital of Bengal, to try to stem violence by his personal presence and then a fast for unity. The results were such that Mountbatten, the last Viceroy, noted that Gandhi had achieved by moral persuasion what four Divisions of the army could probably not have done ${ }^{22}$. However, across the subcontinent the long-term repercussions of communal violence have continued to bedevil public and private life - in the conflicts between India and Pakistan, in continued suspicion and hostility between religious communities in both countries, and in the private suffering, often silently born ${ }^{23}$, by those who witnessed and sometimes committed atrocities, whose wounds have never been healed. They are testimony to the accuracy of Gandhi's sense of the power of violence in the name of religion, and of his own sense of failure to find lasting solutions to a problem which was far more complex than even he realised.

Despite what looks like failures in Gandhi's own life, he remains an immensely powerful and attractive public figure who has become international 'property' and inspiration to many since his death. In part this is related to the great need for peaceful solutions to seemingly intractable political and socioeconomic problems, and the hope that Gandhian satyagraha might provide an alternative to violence and political compromise. But there is also a way in which Gandhi has become an inspiration for those who feel imprisoned by their own religious traditions, or who fail to gain inspiration from any organised or established 'religion'.

As this essay noted earlier, Gandhi understood true religion to be the individual's quest for Truth deep within each living person. It was not defined in terms of creed or dogma, and it was not guarded by specialist practitioners or hierarchical structures. It was also very eclectic in its spiritual and theological understandings and its practices of worship. Not surprisingly many people were drawn to Gandhi and his simple ashram communities in his own life time. He had a profoundly attractive and welcoming personality: some would have said he was charismatic. But those who associated with him were drawn by more than his personality. Some were Indians who were trying to

${ }^{22}$ Cf. Campbell-Johnson, Mission with Mountbatten (1951:181). CampbellJohnson was Mountbatten's Press attaché.

${ }^{23}$ For a profoundly moving account of this, see Urvashi Butalia, The Other Side of Violence: Voices from the Partition of India (1998). 


\section{Judith Brown}

find a way of living within their religious traditions while being empowered to live morally in a changing world, without being held back by enervating traditions. There were many such earnest seekers in the India of Gandhi's time and in the generations before him who were confronted particularly in the nineteenth century with the challenges of other 'world religions' and the contrast between new social sensitivities and the restricting and seemingly unchanging nature of many of India's religious traditions ${ }^{24}$. Gandhi was a breath of fresh air when he claimed that religious ideas were always evolving.

Only God is changeless and as His message is received through the imperfect human medium, it is always liable to suffer distortion in proportion as the medium is pure or otherwise ${ }^{25}$.

Here was justification for religious reform, for challenge to existing tradition, and for openness to new insights. Foreigners who came to his ashrams and worked with him were often people who were on the fringes of their own religious traditions or had virtually abandoned them ${ }^{26}$. Gandhi's preaching and the religious practices in his ashrams allowed people to seek for a spirituality which seemed truthful to them, unfettered by creeds, the notion of unchanging authoritative tradition, or a priestly class. It was also supremely practical, leading to a simple life style and to service of others.

Of course many people then and now have found their religious traditions to be liberating and sustaining, giving them a structure of faith and practice within which they can move to greater depths of spiritual sensitivity, and which motivates them for public service. Gandhi's ideal was never to encourage people to leave their faith traditions but to become better believers within them. As he wrote in 1924, he believed that the world's main religious traditions were equally true though personally Hindu tradition gave him all he needed,

${ }^{24}$ See Kenneth W. Jones, Socio-religious Reform Movements in British India (1989).

${ }^{25}$ Young India, 4 September 1924, in J. Brown (ed.), Gandhi: The Essential Writings (2008: 52f).

${ }^{26}$ One interesting British follower of Gandhi was C.F. Andrews, one-time Christian missionary. He did finally return to Christianity. See H. Tinker, The Ordeal of Love: C.F. Andrews and India (1980). 
It contains all that I need for my growth. It teaches me to pray not that others may believe as I believe but that they may grow to their full height in their own religion. My constant prayer therefore is for a Christian or a Mussalman to be a better Christian and a better Mahomedan. I am convinced, I know, that God will ask, asks us now, not what we label ourselves but what we are, i.e., what we do. With Him deed is everything, belief without deed is nothing. With Him doing is believing ${ }^{27}$.

For Gandhi therefore all true religion, within or outside a named religious tradition, consisted of seeking for Truth and growing in self-understanding and therefore growing in perception of the divine.

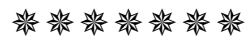

This essay has examined three significant themes in the life, work and thought of Mahatma Gandhi. We have seen how, in the context of early $20^{\text {th }}$ century India, he wrestled with the role of dominant religious traditions in sustaining varieties of power structures and inequalities, the connection between religious beliefs and organizations and violence, and the quest for an authentic and active spirituality in a changing context where many 'religions' seemed to fail to meet the needs of serious seekers after meaning and truth. These are themes which Martin Prozesky has often addressed in his own academic and more public work in the very different context of South Africa during and immediately after apartheid. They are indeed enduring issues which will always confront men and women in their thinking and their practice. It is for this reason that I gave as the title to this paper, 'Gandhi: a man for our times?' When Martin, and indeed many of us, were starting our academic careers, and engaging in the study of history, politics and religion, there were some who predicted the march of 'secularization' and the death of religion as a force in public life. If ever a prediction was proved wrong this was perhaps one of the most egregious. We know from events around us the continuing power of religious traditions and organizations, and the ways in which some of them sustain social

${ }^{27}$ Young India, 4 September 1924, in J. Brown (ed.), Gandhi: The Essential Writings (2008: 53). 
and political power structures, and justify profound inequalities. We see their links to local and international acts of violence. We can see, too, the influence of varieties of fundamentalisms, and the dangers where serious scholarly reflection on the nature of scripture and tradition is absent. It is therefore as urgent as it has been in the past that new generations of scholars should continue to examine these issues which cross established academic disciplines, that they should engage with men and women in the past who were as thoughtful on these issues in their own times, and that they should contribute to public as well as academic debate.

\section{References}

Brown, J.M. \& M. Prozesky (eds.) 1996. Gandhi and South Africa: Principles and Politics. Pietermaritzburg: University of Natal Press.

Brown, J.M. (ed.) 2008. Mahatma Gandhi: The Essential Writings. New Edition. Oxford: Oxford University Press.

Brown, J.M. 2009. Chapter 3: Gandhi and Civil Resistance in India, 1917 -

1947: Key Issues. In Roberts, A. \& T. Garton Ash (eds.): Civil Resistance and Power Politics: The Experience of Non-violent Action from Gandhi to the Present. Oxford: Oxford University Press.

Butalia, U. 1998. The Other Side of Violence. Voices from the Partition of India. New Delhi: Penguin Books India.

Campbell-Johnson, A. 1951. Mission with Mountbatten. London: Robert Hale. Gandhi, M. 1909. Hind Swaraj. CWMG Volume x: 6-68. Delhi: Government of India Printers.

Gandhi, M. 1927. An Autobiography. The Story of My Experiments with Truth. Desai, M. (trans.). Ahmedabad: Navajivan Press.

Gandhi, M. 1928. Satyagraha in South Africa. Desai, V.G. (trans.). Ahmedabad: Navajivan Press.

Gandhi, M. 1958-. Collected Works of Mahatma Gandhi (CWMG). Delhi: Government of India Printers.

Gandhi, M. 1997. Hind Swaraj and Other Writings. Parel, A.J. (ed.). Cambridge: Cambridge University Press.

Jones, K.W. 1989. Socio-religious Reform Movements in British India. Cambridge: Cambridge University Press.

Khan, Y. 2007. The Great Partition: The Making of India and Pakistan. New 
Haven \& London: Yale University Press.

Roberts, A. \& T. Garton Ash (eds.) 2009. Civil Resistance and Power Politics:

The Experience of Non-violent Action from Gandhi to the Present. Oxford: Oxford University Press.

Talbot, I. \& G. Singh 2009. The Partition of India. Cambridge: Cambridge University Press.

Tinker, H. 1980. The Ordeal of Love: C.F. Andrews and India. Delhi: Oxford University Press.

Judith M. Brown

Emeritus Professor

Former Beit Chair of Commonwealth History

Oxford University judith.brown@history.ox.ac.uk 